\title{
Purchasing Factors for Travel Insurance by Asian Consumers
}

\author{
Shao-Ping Wang \\ Dept. of Business Management, Nanhua University \\ No. 55., Sec. 1, Nanhua Rd., Dalin, Chiayi, Taiwan, R.O.C \\ E-mail: 10480006@nhu.edu.tw \\ Li-Chun Chen \\ Dept. of Tourism Management, Nanhua University \\ No. 55., Sec. 1, Nanhua Rd., Dalin, Chiayi, Taiwan, R.O.C \\ E-mail: 10253020@nhu.edu.tw \\ Miao-Sheng Chen \\ Dept. of Business Management, Nanhua University \\ No. 55., Sec. 1, Nanhua Rd., Dalin, Chiayi, Taiwan, R.O.C \\ E-mail: mschen@mail.nhu.edu.tw
}

\author{
Mou-Jian Li \\ Dept. of Tourism Management, Nanhua University \\ No. 55., Sec. 1, Nanhua Rd., Dalin, Chiayi, Taiwan, R.O.C \\ E-mail: mjlee@mail.nhu.edu.tw
}

Received: Oct. 30, 2018 Accepted: Feb. 11, 2019 Online published: Feb. 19, 2019

doi:10.5296/ijhrs.v9i1.14171 URL: https://doi.org/10.5296/ijhrs.v9i1.14171 


\section{Abstract}

Purpose: This study is mainly to explore the key factors for consumers to purchase travel safety insurance, and to understand the relative importance of evaluation factors from the statistics, so as to sort out the evaluation items of the main and sub-criteria and to evaluation the weights of items.

Design/methodology/approach: This study employed a questionnaire and the analytic hierarchy process (AHP) to evaluate and select key factors for travel insurance products. Furthermore, the consistency of each questionnaire item was verified to guarantee the validity of the analytical results.

Findings: These results indicate that consumers primarily consider insurance benefits when making overseas travel insurance purchasing decisions, including insurance content and the coverage value. This key factor significantly affects consumers purchasing overseas travel insurance, and helps salespeople and insurance companies understand how to help customers plan their overseas travel insurance.

Originality/Value: 1.Life and property insurance companies sell travel insurance products. 2. Insurance salespeople should also introduce the content of travel insurance so that travelers understand the protection and benefits offered. 3.Property insurance companies target "young people" and advertise travel insurance products on a website. 4.Increasing number of sudden illnesses such as stroke and myocardial infarction occur during travel. 5.Call-in cards are convenient for today's busy consumers, but also actively promote and explain call-in cards when engaging with consumers to encourage them to sign up sooner. 6.Consumers also emphasize the financial health of insurance companies.

Keywords: travel safety insurance, key factors, Asian consumer

\section{Introduction}

The effect of risk on our everyday lives is ubiquitous; thus, we must respond to it to guarantee our security and property. We can analyse and measure potential risks in various areas, and use insurance to pre-emptively avoid and minimise these risks, thereby reducing and distributing the risk of individual loss (Wu, 2003). As such, insurance can be used to distribute risk and reduce personal and financial losses due to accidents. Furthermore, insurance has become an effective tool used to safeguard peoples' lives and property.

While travelling, traveler's face the issue of increased risk. According to data from a survey conducted by the Life Insurance Association of the Republic of China (LIAROC), the Taiwanese made 9.4 million trips abroad in 2008, but they purchased only comprehensive overseas travel insurance (travel insurance) for 2.5 million of these trips. This indicates that tourists generally overlook the risks of travelling to foreign countries, and should further consider safeguarding their extended travel plans (Chang, 2013). The risk of accidents exists in everyday living environments and is even more likely when travelling. This is especially true of overseas travel, because when visiting a new place with unfamiliar customs, one is unable to assess the risk index of the environment. Thus, ordinary risk levels increase greatly 
when travelling, because most tourists are relaxed and shift to their travel agent the responsibility for being observant and potential risks. In this context, accidents often occur during the carefree travel pleasure.

Travelling is a human activity in which risk stems from a combination of sources. In general, factors that affect the risk of travel accidents include transportation methods used during travel, facilities provided by the destination, similarities and differences in geography and climate, unique local customs and taboos, and different living environments (Wu, 2003; Wilks, 2004). This confirmed that most accidents concerning tourist areas are related to car and water. These accidents have been ranked on four levels according to the severity of their results: death, hospitalization, clinical treatment, and other health-related problems.

According to statistics computed by the life insurance industry, only one in ten domestics Taiwanese travellers purchase travel insurance, and most rely on the mandate of tour groups to insure tourists. However, during overseas travel, $68 \%$ of people purchase travel insurance themselves. This indicates that the willingness of the Taiwanese public to purchase travel insurance products for overseas travel is gradually increasing, showing their increasing acknowledgement of the risk of accidents when travelling abroad. However, a lack of emphasis on domestic travel insurance remains, and when accidents do occur, the large medical expenses incurred often place significant pressures on families. Because the risk of accidents does not vary according to location, the Taiwanese public should equally emphasize domestic and overseas travel insurance.

The subjects of this study are supervisors above the management level from the production, government, and academic sectors; insurance companies; employees of the competent departments of city and county-level tourism bureaus; and professors from relevant university departments. The questionnaire content was obtained from relevant theoretical literature and revised by experts. As such, the content of questionnaire items was validated by experts. Questionnaires were completed through one-on-one interviews, after which the empirical data for this study were collected.

\section{Literature Review}

\subsection{Travel Insurance}

Insurance is primarily a method that distributes personal risk by providing protection against a possible eventuality. "Travel insurance" is an insurance product designed for use by different types of travellers such as those who travel for business or visiting relatives, and students during their domestic and overseas travel (Gee, Makens, and Choy, 1996). During travel and within the valid term of an insurance policy, in the event of an accident in which the insured person suffers a bodily injury resulting in accidental death and dismemberment (AD\&D), the insurance company must abide by the terms of the contract and compensate the beneficiary of the policy (Taiwan Insurance Institute, https://www.tii.org.tw/opencms/english/index.html ). Travellers can also add injury treatment insurance to cover medical costs resulting from accidental injuries during their travels. Currently, Taiwan offers three types of travel insurance, as shown in Table I. 
Table I. Types of Taiwanese travel insurance

\begin{tabular}{|c|c|c|c|}
\hline & $\begin{array}{l}\text { Travel Industry Liability } \\
\text { Insurance }\end{array}$ & $\begin{array}{l}\text { Credit Card Add-On } \\
\text { Travel Insurance }\end{array}$ & $\begin{array}{l}\text { Comprehensive Travel } \\
\text { Insurance }\end{array}$ \\
\hline $\begin{array}{l}\text { Description } \\
\text { of Insurance } \\
\text { Type }\end{array}$ & $\begin{array}{l}\text { According to the provisions of } \\
\text { the Statute for the Development } \\
\text { of Tourism and Regulations for } \\
\text { Tourism Industry Management, } \\
\text { operators must insure tour } \\
\text { members prior to departure. }\end{array}$ & $\begin{array}{l}\text { A credit card must be } \\
\text { used to pay for at least } \\
80 \% \text { of the tour group } \\
\text { costs or total cost of } \\
\text { transportation tickets. }\end{array}$ & $\begin{array}{l}\text { Members of the public } \\
\text { may autonomously } \\
\text { purchase insurance } \\
\text { policies from insurance } \\
\text { companies. }\end{array}$ \\
\hline $\begin{array}{l}\text { Protection } \\
\text { Period }\end{array}$ & During the period of travel & $\begin{array}{l}\text { Only offers protection } \\
\text { during the period of air } \\
\text { travel, or on fixed routes } \\
\text { of public transportation }\end{array}$ & $\begin{array}{l}\text { Complete duration of } \\
\text { travel }\end{array}$ \\
\hline $\begin{array}{l}\text { Protection } \\
\text { Content }\end{array}$ & $\begin{array}{l}\text { 1. Accidental death of tour } \\
\text { group members } \\
\text { 2. Injury treatment for tour } \\
\text { group members } \\
\text { 3. Aftermath maintenance } \\
\text { fees } \\
\text { 4. Loss of travel documents }\end{array}$ & $\begin{array}{l}\text { 1. AD \& D } \\
\text { 2. Travel inconvenience } \\
\text { The following items are } \\
\text { not generally included, } \\
\text { and are determined by the } \\
\text { credit card provider: } \\
\text { 3. Injury treatment } \\
\text { 4. Sudden illness while } \\
\text { overseas } \\
\text { 5. Overseas emergency } \\
\text { services }\end{array}$ & $\begin{array}{l}\text { 1. AD \& D } \\
\text { 2. Injury treatment } \\
\text { 3. Personal liability } \\
\text { insurance } \\
\text { 4. Sudden illness while } \\
\text { overseas } \\
\text { 5. Travel inconvenience } \\
\text { insurance (eight } \\
\text { major items including } \\
\text { loss of luggage) } \\
\text { 6. Overseas emergency } \\
\text { services }\end{array}$ \\
\hline $\begin{array}{l}\text { Insured } \\
\text { Amount }\end{array}$ & $\begin{array}{l}\text { Minimum accidental death } \\
\text { coverage amount: NT\$2 } \\
\text { million; injury treatment NT\$3 } \\
\text { million }\end{array}$ & $\begin{array}{l}\text { Coverage amount varies } \\
\text { according to the type of } \\
\text { credit card }\end{array}$ & $\begin{array}{l}\text { May be adjusted } \\
\text { according to individual } \\
\text { requirements; coverage } \\
\text { ranges from around } \\
\text { NT\$ } 100,000 \text { to } 10 \\
\text { million }\end{array}$ \\
\hline
\end{tabular}

\subsection{Consumer Purchasing Behaviour and Decision Making}

Consumer purchasing behaviour is defined as understanding the following elements when consumers purchase products and services: what brand is being purchased (what), how much is purchased (how), where is it purchased (where), why is it purchased (why), when is it purchased (when), and who is it purchased from (who) (Schiffman and Kanuk, 1987). If marketers understand consumers' purchasing decision-making process before their competitors, grasp their thinking process, and utilise their responses to various marketing tools, they will maintain a competitive advantage.

Kotler (1997) argued that purchasing decisions are stimulated by external factors that consumers encounter (marketing activities and environment), and consumer purchasing decisions are generated after being processed by the buyer's black box (consumer characteristics and decision-making process). However, Engel, Blackwell, and Miniard (1993) distinguished the following seven steps in the purchasing decision-making process: need 
identification, information search, evaluation of alternatives, purchase, consumption, post-consumption evaluation, and disposal. These steps are further delineated into three stages: the pre-purchase stage, purchase stage, and post-purchase stage. Morrison (1997) noted two groups of factors that affect consumer travel decision making, namely personal and external factors. Personal factors include needs, hopes, motivations, perception, learning, personality traits, lifestyle, self-concepts, and seeking excitement. External factors include culture and subculture, reference groups, social status, opinion leaders, family, tourist site security, and political instability. Table II provides definitions of consumer decision making by various scholars.

Table II. Definitions of consumer purchase decision making

\begin{tabular}{|c|c|c|}
\hline Academics & Year & Definition \\
\hline $\begin{array}{l}\text { Engel, Miniard, \& } \\
\text { Blackwell }\end{array}$ & 1993 & $\begin{array}{l}\text { Consumer decision making is defined as each activity involved in } \\
\text { consumers retrieving, consuming, and handling products and services, } \\
\text { in addition to events that occur before and after these activities. }\end{array}$ \\
\hline Schiffman \& Kanuk & 2003 & $\begin{array}{l}\text { Consumer purchase decision making includes consumers' search, } \\
\text { purchase, use, evaluation, and handling behaviours to satisfy their } \\
\text { demands regarding products, services, and ideas. }\end{array}$ \\
\hline $\begin{array}{l}\text { Yu Chaoquan \& } \\
\text { Zhang Jialin }\end{array}$ & 1997 & $\begin{array}{l}\text { In general, when consumers face purchasing decisions, they adopt a } \\
\text { problem-solving attitude. This means that consumers in the Stage } \\
\text { Model of the purchasing process face internal and external influences } \\
\text { and problem-solving processes related to five stages: problem } \\
\text { identification, information gathering, evaluation of alternatives, } \\
\text { purchasing decision making, and post-purchasing behaviour. }\end{array}$ \\
\hline $\begin{array}{l}\text { Lin Suzhen \& Ding } \\
\text { Xueqin }\end{array}$ & 1999 & $\begin{array}{l}\text { Purchasing decision making includes assessing values such as brand, } \\
\text { quality, service, and promotional activities, and using questionnaire } \\
\text { surveys to collect data and measure variables. }\end{array}$ \\
\hline Cai Kunzhe & 2005 & $\begin{array}{l}\text { Consumer purchase decision making is defined as the various elements } \\
\text { that consumers pay attention to when making purchasing decisions, } \\
\text { such as product, access, price, and promotion. }\end{array}$ \\
\hline Huang Jingqin & 2007 & $\begin{array}{l}\text { Consumer purchase decision making refers to each activity related to } \\
\text { accessing, consuming, and handling a product or service, and includes } \\
\text { the decisions made before and after these activities. }\end{array}$ \\
\hline
\end{tabular}

To summarise the arguments discussed above, consumer purchase decision making includes various activities conducted before a consumer directly acquires, consumes, and handles a product or service. Cultural, social, personal, and psychological factors affect consumer lifestyles, while personality traits influence people's decisions to purchase life insurance and their purchase decision-making process.

\subsection{Literature on Travel Insurance}

Table III lists the literature related to travel insurance consumption in the Taiwan region. 
Table III. Definitions of consumer purchase decision making

\begin{tabular}{llll}
\hline Author & Year & Research topic & Research subject \\
\hline Wu Manli & 2003 & $\begin{array}{l}\text { Taiwanese peoples' understanding of travel risks in } \\
\text { overseas travel and travel insurance purchasing } \\
\text { behaviour }\end{array}$ & $\begin{array}{l}\text { Taiwanese people who } \\
\text { travelled overseas } \\
\text { within the last year }\end{array}$ \\
\hline Yan Huiling & 2005 & $\begin{array}{l}\text { Influence of primary school teachers' personality } \\
\text { traits, lifestyle, and travel risk perception on travel } \\
\text { insurance consumption: A case study of Kaohsiung } \\
\text { City }\end{array}$ & $\begin{array}{l}\text { Primary school teachers } \\
\text { in Kaohsiung City }\end{array}$ \\
\hline Qiu Yiyi & 2006 & $\begin{array}{l}\text { Consumer understanding of and purchasing } \\
\text { intention toward travel insurance offered by } \\
\text { property insurance companies }\end{array}$ & $\begin{array}{l}\text { Consumers aged 20-65 } \\
\text { years }\end{array}$ \\
\hline Yang Xinyu & 2012 & Ecotourism risks and insurance plans & $\begin{array}{l}\text { Case study data and } \\
\text { case analysis }\end{array}$ \\
\hline & & $\begin{array}{l}\text { Influence of tourist personality traits, travel type, } \\
\text { risk management, travel risk and perception, and } \\
\text { information gathering on travel insurance } \\
\text { consumption behaviour }\end{array}$ & $\begin{array}{l}\text { Consumers with } \\
\text { overseas travel } \\
\text { experience over the } \\
\text { past five years }\end{array}$ \\
\hline
\end{tabular}

After considering the abovementioned research, this study defines consumption behaviour related to travel insurance as follows. While travelling or participating in activities, consumers may encounter or experience unpredictable circumstances such as accident, sudden illness, lost money or property, or delays and rescheduling caused by weather or human factors. To reduce personal expense and effort due to such circumstances, they can obtain appropriate assistance or financial reimbursement and transfer their risk during travel to an insurance company, thus engaging in travel insurance purchasing behaviour.

\subsection{Criteria for Evaluating Insurance Products}

Key factors in the assessment criteria when purchasing insurance products. To summarise the descriptions of elements of insurance products above, this paper presents five elements of travel insurance products: corporate image, salesperson quality, access to purchase, purchase experience, and insurance benefits, and 24 evaluation indices. Table IV shows the questionnaire items. 
Table IV. Content of questionnaire items

\begin{tabular}{|c|c|c|c|}
\hline & Main criteria & Sub-criteria & Reference literature \\
\hline 1 & $\begin{array}{l}\text { Corporate } \\
\text { Image }\end{array}$ & $\begin{array}{l}\text { Reputation, financial health, claims service, } \\
\text { after-sales service, service location, whether the } \\
\text { company is a holding company }\end{array}$ & $\begin{array}{l}\text { Song Wenxi (2004) } \\
\text { Bai Xiangyi (2010) }\end{array}$ \\
\hline 2 & $\begin{array}{l}\text { Salesperson } \\
\text { Quality }\end{array}$ & $\begin{array}{l}\text { Service attitude, professional knowledge, academic } \\
\text { background, professional certification, years of } \\
\text { experience }\end{array}$ & $\begin{array}{l}\text { Fang Huizhen (2004) } \\
\text { Jian Binren (2008) }\end{array}$ \\
\hline 3 & $\begin{array}{l}\text { Access to } \\
\text { Purchase }\end{array}$ & $\begin{array}{l}\text { Life insurance company, property insurance } \\
\text { company, insurance broker, online purchase, } \\
\text { CALL-IN card, airport counter }\end{array}$ & $\begin{array}{l}\text { Chang Yuanchang } \\
(2002) \\
\text { Bai Xiangyi (2010) }\end{array}$ \\
\hline 4 & $\begin{array}{l}\text { Purchase } \\
\text { Experience }\end{array}$ & $\begin{array}{l}\text { Relatives, friends, and family members, previously } \\
\text { used insurance company, salesperson of the previous } \\
\text { policy }\end{array}$ & $\begin{array}{l}\text { Chang Yuanchang } \\
(2002) \\
\text { Jian Binren (2008) }\end{array}$ \\
\hline 5 & $\begin{array}{l}\text { Insurance } \\
\text { Benefits }\end{array}$ & $\begin{array}{l}\text { Accidental injury and death, accident outpatient and } \\
\text { hospitalisation, sudden outpatient and } \\
\text { hospitalisation, overseas emergency assistance, loss } \\
\text { of property }\end{array}$ & $\begin{array}{l}\text { Chang Yuanchang } \\
(2002) \\
\text { Bai Xiangyi (2010) }\end{array}$ \\
\hline
\end{tabular}

\section{Research Methods}

This study employed a questionnaire and the analytic hierarchy process (AHP) to evaluate and select key factors for travel insurance products. Furthermore, the consistency of each questionnaire item was verified to guarantee the validity of the analytical results. Tables $\mathrm{V}$ and VI provide explanations of the main criteria and sub-criteria for each element.

Table V. Main criteria for elements

\begin{tabular}{|c|c|}
\hline Element & Description \\
\hline $\begin{array}{l}\text { A. Corporate } \\
\text { Image }\end{array}$ & $\begin{array}{l}\text { The "reputation" of the company in the industry and market, speed of "claims } \\
\text { services," number and convenience of "service locations" set up by the company, } \\
\text { "financial health of the company," and "whether it is a holding company" that can } \\
\text { provide various products and services }\end{array}$ \\
\hline $\begin{array}{l}\text { B. Salesperson } \\
\text { Quality }\end{array}$ & $\begin{array}{l}\text { Depth of "professional knowledge" and ability to provide more opinions to the } \\
\text { consumer, "service attitude" when dealing with consumers, "educational } \\
\text { background," "years of experience" to which the salesperson can refer, and number } \\
\text { of "professional certifications" }\end{array}$ \\
\hline $\begin{array}{l}\text { C. Access to } \\
\text { Purchase }\end{array}$ & $\begin{array}{l}\text { Consumers can purchase products through "life insurance companies," "property } \\
\text { insurance companies," agents who help insurance companies ("insurance brokers"), } \\
\text { or online and without the assistance of salespeople ("online purchase"). Before } \\
\text { engaging in purchasing behaviours, consumers can sign a contract so that before } \\
\text { leaving for their travels, they can use a } 0800 \text { service to directly confirm their } \\
\text { insurance amount and have the cost directly charged to the credit card used in the } \\
\text { contract. This is called a "CALL-IN Card." In addition, insurance products sold at } \\
\text { airports are referred to as the "airport counter." }\end{array}$ \\
\hline $\begin{array}{l}\text { D. Purchase } \\
\text { Experience }\end{array}$ & $\begin{array}{l}\text { Insurance companies recommended by "relatives, friends, and family members," } \\
\text { "previously used insurance companies," and "salesperson of the previous policy" }\end{array}$ \\
\hline $\begin{array}{l}\text { E. Insurance } \\
\text { Benefits }\end{array}$ & $\begin{array}{l}\text { Insurance for "accidental injury or death" caused by accidents, "accident outpatient } \\
\text { and hospitalisation," "outpatient or hospitalisation for sudden illness" not caused by } \\
\text { an accident, "overseas emergency assistance" for events occurring overseas, and } \\
\text { "loss of property" of individuals }\end{array}$ \\
\hline
\end{tabular}


Table VI. Descriptions of sub-criteria for assessment

\begin{tabular}{ll}
\hline Assessment criterion & Description \\
\hline A1. Reputation & Size and overall reputation of company \\
A2. Claims Service & Speed and service method previously provided by the \\
& company for claims \\
A3. Service Location & Number of locations providing customer service \\
A4. Financial Health & Overall level of financial health \\
A5. Holding Company Member & Whether or not the company is a member of a \\
& holding company
\end{tabular}

\begin{tabular}{|c|c|}
\hline B1. Professional Knowledge & $\begin{array}{l}\text { Ability of the salesperson to demonstrate professional } \\
\text { knowledge }\end{array}$ \\
\hline B2. Service Attitude & $\begin{array}{l}\text { Service attitude perceived by customer throughout the overall } \\
\text { purchase process }\end{array}$ \\
\hline B3. Academic Background & Academic background of the salesperson \\
\hline B4. Years of Experience & Years of work experience in relevant fields \\
\hline B5. Professional Certification & Number of professional certifications \\
\hline C1. Insurance Company & Life insurance company \\
\hline C2. Property Insurance Company & Property insurance company \\
\hline C3. Insurance Broker & \\
\hline C4. Online Purchase & Sales services outsourced by the insurance company \\
\hline C5. Call-in card & Autonomous purchase of insurance online \\
\hline C6. Airport Counter & $\begin{array}{l}\text { After previously signing a contract, insurance can be } \\
\text { purchased by phone prior to traveling } \\
\text { Counters set up by insurance companies at airports for } \\
\text { travellers to purchase insurance }\end{array}$ \\
\hline D1. Relative, Friend, or Family Member & $\begin{array}{l}\text { Insurance policies introduced by close friends and relatives } \\
\text { who have purchasing experience with the policy }\end{array}$ \\
\hline $\begin{array}{l}\text { D2. Previously Used Insurance Company } \\
\text { D3. Salesperson of Previous Policy }\end{array}$ & $\begin{array}{l}\text { Insurance companies from which one has previously } \\
\text { purchased insurance } \\
\text { The salesperson who sold one's previous policy }\end{array}$ \\
\hline E1. Accidental Injury and Death & Payment in the case of $\mathrm{AD} \& \mathrm{D}$ \\
\hline E2. Accidental Outpatient and & Outpatient treatment or hospitalisation resulting \\
\hline Hospitalisation & from an accident \\
\hline E3. Sudden Illness Outpatient and & Outpatient treatment or hospitalisation resulting \\
\hline Hospitalisation & from sudden illness \\
\hline E4. Overseas Emergency Assistance & $\begin{array}{l}\text { The insurance company dispatches an overseas emergency } \\
\text { services company to help with medical treatment and other }\end{array}$ \\
\hline E5. Property Loss Insurance & matters at the site of travel \\
\hline & $\begin{array}{l}\text { Compensation for losses incurred from lost or } \\
\text { stolen property during travel }\end{array}$ \\
\hline
\end{tabular}


In addition to helping decision makers conduct a hierarchical analysis of problems and clarify their roots and conclusions, the AHP also derives the relative importance of several alternatives (their weights), which the decision makers can consult when making decisions (Jian, 2008). This method is primarily applied to decision-making problems with multiple evaluation criteria in conditions of uncertainty (Deng and Ceng, 1989). Saaty (1980) argues that the AHP includes both quantitative measurement and qualitative factors to measure all important tangible and intangible variables. As such, the AHP can establish a clear ranking of tangible and intangible variables. Table VII provides the significance and description of the evaluation scale.

Table VII. Significance and description of evaluation scale

\begin{tabular}{lll}
\hline Evaluation scale & Definition & Description \\
\hline 1 & Equal Importance & $\begin{array}{l}\text { Levels of contribution of the two alternatives } \\
\text { being compared are equally important }\end{array}$ \\
\hline 3 & Weak Importance & $\begin{array}{l}\text { Experience and judgment slightly prefer one } \\
\text { alternative }\end{array}$ \\
\hline 5 & Essential Importance & $\begin{array}{l}\text { Experience and judgment strongly prefer one } \\
\text { alternative }\end{array}$ \\
\hline 9 & Very Strong & $\begin{array}{l}\text { An extremely strong preference for one alternative } \\
\text { is demonstrated }\end{array}$ \\
\hline $2,4,6,8$ & Absolute Importance & $\begin{array}{l}\text { There is sufficient evidence to affirm the absolute } \\
\text { preference for one alternative }\end{array}$ \\
\hline
\end{tabular}

\section{Results and Analyses}

\subsection{Questionnaire Sample Analysis}

The demographic statistics in this study included three items: "gender," "age," and "years of experience." Table VIII provides the results of the basic attribute analysis.

Table VIII. Analysis of personal background data

\begin{tabular}{|c|c|c|c|}
\hline Type & Item & Number & Percentage \\
\hline \multirow{2}{*}{ Gender } & Male & 12 & $40 \%$ \\
\hline & Female & 18 & $60 \%$ \\
\hline \multirow{4}{*}{ Age } & $21-30$ & 5 & $17 \%$ \\
\hline & $31-40$ & 7 & $23 \%$ \\
\hline & $41-50$ & 10 & $33 \%$ \\
\hline & $50+$ & 8 & $27 \%$ \\
\hline \multirow[t]{2}{*}{ Years of Experience } & $1-10$ & 12 & $40 \%$ \\
\hline & $10+$ & 18 & $60 \%$ \\
\hline \multirow{3}{*}{$\begin{array}{l}\text { Professional } \\
\text { Background }\end{array}$} & Life Insurance Company & 10 & $33.3 \%$ \\
\hline & $\begin{array}{l}\text { Culture and Tourism Bureau } \\
\text { Staff }\end{array}$ & 10 & $33.3 \%$ \\
\hline & $\begin{array}{l}\text { Department of Tourism } \\
\text { University Student }\end{array}$ & 10 & $33.3 \%$ \\
\hline
\end{tabular}


This study distributed 35 questionnaires and collected 30 completed ones to obtain data on experts. The AHP was used to conduct pairwise comparisons between criteria, and Excel was used to obtain the geometric mean after summarising the data. We used Super Decisions software to calculate within the pairwise comparison matrix. To conduct a consistency check, relative weights were determined according to eigenvector values, which serve as a consistency index (C.I.). Saaty (1980) suggests that the acceptable degree of error should be within 0.1 (a consistency ratio [C.R.] of $<0.1$ is typically used) for the pairwise comparison matrix constructed through question verification, regardless of whether the matrix is consistent, for assessment by both the decision maker and entire hierarchical structure. This study adopted a C.R. of $<0.1$ as a verification standard, where C.I. $<0.1$, indicating that the consistency index has been satisfied and the consistency ratio met. Otherwise, the questionnaire had to be reworked or deleted. This study met consistency standards by removing the questionnaire data that did not satisfy the consistency ratio. Tables IX and $\mathrm{X}(\mathrm{a})-(\mathrm{e})$ show the criterion pairwise comparison matrices.

Tables IX. Pairwise comparison matrix for main criteria

\begin{tabular}{lllllllc}
\hline Travel insurance & $\begin{array}{l}\text { Corporate } \\
\text { reputation }\end{array}$ & $\begin{array}{l}\text { Salesperson } \\
\text { quality }\end{array}$ & $\begin{array}{l}\text { Access to } \\
\text { purchase }\end{array}$ & $\begin{array}{l}\text { Purchase } \\
\text { experience }\end{array}$ & $\begin{array}{l}\text { Insurance } \\
\text { benefits }\end{array}$ & $\begin{array}{l}\text { Hierarchical } \\
\text { weight }\end{array}$ & Rank \\
\hline $\begin{array}{l}\text { Corporate } \\
\text { Reputation }\end{array}$ & 1 & 1.1675 & 1.4376 & 1.3111 & 1.6321 & 0.175 & 3 \\
\hline $\begin{array}{l}\text { Salesperson } \\
\text { Quality }\end{array}$ & 0.856531 & 1 & 2.7904 & 1.5704 & 2.3969 & 0.203 & 2 \\
\hline $\begin{array}{l}\text { Access to } \\
\text { Purchase }\end{array}$ & 0.695604 & 0.358372 & 1 & 2.1048 & 2.7533 & 0.097 & 5 \\
\hline $\begin{array}{l}\text { Purchase } \\
\text { Experience }\end{array}$ & 0.762718 & 0.63678 & 0.475105 & 1 & 2.3052 & 0.173 & 4 \\
\hline Insurance Benefits 0.612708 & 0.417206 & 0.363201 & 0.433802 & 1 & 0.349 & 1 \\
\hline
\end{tabular}

Tables X(a). Pairwise comparison matrix for the sub-criterion "corporate reputation"

\begin{tabular}{|c|c|c|c|c|c|c|c|}
\hline Corporate image & Reputation & $\begin{array}{l}\text { Claims } \\
\text { service }\end{array}$ & $\begin{array}{l}\text { Service } \\
\text { location }\end{array}$ & $\begin{array}{l}\text { Financial } \\
\text { health }\end{array}$ & $\begin{array}{l}\text { Member of } \\
\text { holding } \\
\text { company }\end{array}$ & $\begin{array}{l}\text { Hierarchical } \\
\text { weight }\end{array}$ & Rank \\
\hline Reputation & 1 & 2.48818 & 1.56936 & 1.71909 & 1.0012 & 0.118 & 4 \\
\hline Claims Service & 0.4019 & 1 & 3.9034 & 2.1879 & 3.6067 & 0.417 & 1 \\
\hline $\begin{array}{l}\text { Service } \\
\text { Location }\end{array}$ & 0.637202 & 0.256187 & 1 & 1.59007 & 2.0394 & 0.152 & 3 \\
\hline Financial Health & 0.581703 & 0.457059 & 0.628903 & 1 & 2.5279 & 0.215 & 2 \\
\hline $\begin{array}{l}\text { Member of } \\
\text { Holding } \\
\text { Company }\end{array}$ & 0.998801 & 0.277262 & 0.49034 & 0.395585 & 1 & 0.096 & 5 \\
\hline
\end{tabular}


Tables X(b). Pairwise comparison matrix for the sub-criterion "salesperson quality"

\begin{tabular}{llllllll}
\hline $\begin{array}{l}\text { Salesperson } \\
\text { quality }\end{array}$ & $\begin{array}{l}\text { Professional } \\
\text { knowledge }\end{array}$ & $\begin{array}{l}\text { Service } \\
\text { attitude }\end{array}$ & $\begin{array}{l}\text { Academic } \\
\text { background }\end{array}$ & $\begin{array}{l}\text { Years of } \\
\text { experience }\end{array}$ & $\begin{array}{l}\text { Professional } \\
\text { certification }\end{array}$ & $\begin{array}{l}\text { Hierarchical } \\
\text { weight }\end{array}$ & Rank \\
\hline $\begin{array}{l}\text { Professional } \\
\text { Knowledge }\end{array}$ & 1 & 1.1562 & 3.9055 & 2.7667 & 2.1354 & 0.2992 & 2 \\
\hline $\begin{array}{l}\text { Service } \\
\text { Attitude }\end{array}$ & 0.864902 & 1 & 4.9951 & 4.1678 & 2.439 & 0.3718 & 1 \\
\hline $\begin{array}{l}\text { Academic } \\
\text { Background }\end{array}$ & 0.256049 & 0.200196 & 1 & 1.7796 & 3.0303 & 0.0651 & 5 \\
\hline $\begin{array}{l}\text { Years of } \\
\text { Experience }\end{array}$ & 0.361441 & 0.239935 & 0.561924 & 1 & 1.3176 & 0.1071 & 4 \\
\hline $\begin{array}{l}\text { Professional } \\
\text { Certification }\end{array}$ & 0.468296 & 0.410004 & 0.33 & 0.758956 & 1 & 0.1565 & 3 \\
\hline
\end{tabular}

Tables X(c). Pairwise comparison matrix for the sub-criterion "access to purchase"

\begin{tabular}{lllllllll}
\hline $\begin{array}{l}\text { Access to } \\
\text { purchase }\end{array}$ & $\begin{array}{l}\text { Life } \\
\text { insurance } \\
\text { company }\end{array}$ & $\begin{array}{l}\text { Property } \\
\text { insurance } \\
\text { company }\end{array}$ broker & $\begin{array}{l}\text { Onsurance } \\
\text { purchase }\end{array}$ & $\begin{array}{l}\text { Call-in } \\
\text { card }\end{array}$ & $\begin{array}{l}\text { Airport } \\
\text { counter }\end{array}$ & $\begin{array}{l}\text { Hierarchical } \\
\text { weight }\end{array}$ & Rank \\
\hline $\begin{array}{l}\text { Life } \\
\text { Insurance } \\
\text { Company }\end{array}$ & 1 & 1.1391 & 1.4954 & 1.7694 & 1.1263 & 1.0641 & 0.1957 & 1 \\
\hline $\begin{array}{l}\text { Property } \\
\text { Insurance } \\
\text { Company }\end{array}$ & 0.877886 & 1 & 1.0855 & 1.327 & 1.1299 & 1.6233 & 0.1907 & 2 \\
\hline $\begin{array}{l}\text { Insurance } \\
\text { Broker }\end{array}$ & 0.668717 & 0.9212341 & 1.0455 & 1.2495 & 1.2086 & 0.1404 & 5 \\
\hline $\begin{array}{l}\text { Online } \\
\text { Purchase }\end{array}$ & 0.565163 & 0.75358 & 0.95648 & 1 & 1.3236 & 1.4547 & 0.1287 & 6 \\
\hline Call-In Card & 0.887863 & 0.885034 & 0.80032 & 0.755515 & 1 & 1.1966 & 0.1835 & 3 \\
\hline $\begin{array}{l}\text { Airport } \\
\text { Counter }\end{array}$ & 0.939761 & 0.616029 & 0.827404 & 0.687427 & 0.835701 & 1 & 0.1607 & 4 \\
\hline
\end{tabular}

Tables X(d). Pairwise comparison matrix for the sub-criterion "purchase experience"

\begin{tabular}{llllll}
\hline Purchase experience & $\begin{array}{l}\text { Relatives, } \\
\text { friends, and } \\
\text { family members }\end{array}$ & $\begin{array}{l}\text { Previously used } \\
\text { insurance company }\end{array}$ & $\begin{array}{l}\text { Salesperson of } \\
\text { previous } \\
\text { policy }\end{array}$ & $\begin{array}{l}\text { Hierarchical } \\
\text { weight }\end{array}$ & Rank \\
\hline $\begin{array}{l}\text { Relatives, Friends, and } \\
\begin{array}{l}\text { Family Members } \\
\text { Previously Used Insurance }\end{array}\end{array}$ & 1 & 1.2899 & 1.0524 & 0.3495 & 2 \\
$\begin{array}{l}\text { Company } \\
\begin{array}{l}\text { Salesperson of Previous } \\
\text { Policy }\end{array}\end{array}$ & 0.775254 & 1 & 1.7892 & 0.2471 & 3 \\
\hline
\end{tabular}


Tables X(e). Pairwise comparison matrix for the sub-criterion "insurance benefits"

\begin{tabular}{llllllll}
\hline Insurance benefits & AD \& D & $\begin{array}{l}\text { Accidental } \\
\text { outpatient and } \\
\text { hospitalization }\end{array}$ & $\begin{array}{l}\text { Sudden } \\
\text { illness } \\
\text { outpatient }\end{array}$ & $\begin{array}{l}\text { Overseas } \\
\text { emergency } \\
\text { services }\end{array}$ & $\begin{array}{l}\text { Loss of } \\
\text { property }\end{array}$ & $\begin{array}{l}\text { Hierarchical } \\
\text { weight }\end{array}$ & Rank \\
\hline AD \& D & 1 & 1.4575 & 1.2385 & 1.1467 & 2.3862 & 0.2613 & 1 \\
\hline $\begin{array}{l}\text { Accidental } \\
\begin{array}{l}\text { Outpatient and } \\
\text { Hospitalization }\end{array}\end{array}$ & 0.686106 & 1 & 1.0185 & 1.292 & 1.985 & 0.2108 & 3 \\
$\begin{array}{l}\text { Sudden Illness } \\
\text { Outpatient }\end{array}$ & 0.807428 & 0.981836 & 1 & 1.6927 & 2.737 & 0.2478 & 2 \\
$\begin{array}{l}\text { Overseas } \\
\text { Emergency } \\
\text { Services }\end{array}$ & 0.872068 & 0.773994 & 0.590772 & 1 & 2.0238 & 0.182 & 4 \\
\hline Loss of Property & 0.419076 & 0.503778 & 0.365364 & 0.49412 & 1 & 0.098 & 5 \\
\hline
\end{tabular}

\subsection{Discussion and Analysis}

The five variables for the main criteria were corporate image, salesperson quality, access to purchase, purchase experience, and insurance benefits. After weighting and ranking questionnaire data for experts in general and for experts in each field, we obtained C.I. and C.R. Tables XI and XII show the weight coefficients for expert opinions according to field.

Tables XI. Main criteria item weights

\begin{tabular}{lllllllll}
\hline & \multicolumn{2}{l}{$\begin{array}{l}\text { Overall expert } \\
\text { opinion }\end{array}$} & \multicolumn{3}{l}{$\begin{array}{l}\text { Industrial expert } \\
\text { opinion }\end{array}$} & \multicolumn{2}{l}{$\begin{array}{l}\text { Academic expert } \\
\text { opinion }\end{array}$} & \multicolumn{2}{l}{$\begin{array}{l}\text { Government } \\
\text { expert opinion }\end{array}$} \\
\cline { 2 - 10 } & Weight & Rank & Weight & Rank & Weight & Rank & Weight & Rank \\
\hline Corporate Image & 0.17543 & 3 & 0.14621 & 4 & 0.12185 & 4 & 0.19051 & 4 \\
\hline Salesperson Quality & 0.20368 & 2 & 0.19854 & 3 & 0.17248 & 2 & 0.20676 & 2 \\
\hline Access to Purchase & 0.09786 & 5 & 0.07892 & 5 & 0.10954 & 5 & 0.12241 & 5 \\
\hline Purchase Experience & 0.17357 & 4 & 0.24253 & 2 & 0.13659 & 3 & 0.19823 & 3 \\
\hline Insurance Benefits & 0.34945 & 1 & 0.33381 & 1 & 0.45954 & 1 & 0.2821 & 1 \\
\hline
\end{tabular}

Tables XII. Main criteria consistency analysis

\begin{tabular}{|c|c|c|c|c|c|c|c|c|}
\hline & \multicolumn{2}{|c|}{$\begin{array}{l}\text { Overall expert } \\
\text { opinion }\end{array}$} & \multicolumn{2}{|c|}{$\begin{array}{l}\text { Industrial expert } \\
\text { opinion }\end{array}$} & \multicolumn{2}{|c|}{$\begin{array}{l}\text { Academic expert } \\
\text { opinion }\end{array}$} & \multicolumn{2}{|c|}{$\begin{array}{l}\text { Government expert } \\
\text { opinion }\end{array}$} \\
\hline & C.I. & C.R. & C.I. & C.R. & C.I. & C.R. & C.I. & C.R. \\
\hline \multicolumn{9}{|l|}{ Corporate Image } \\
\hline \multicolumn{9}{|l|}{ Salesperson Quality } \\
\hline Access to Purchase & 0.02957 & 0.0264 & 0.0938 & 0.08371 & 0.017 & 0.01517 & 0.0051 & 0.00457 \\
\hline \multicolumn{9}{|l|}{ Purchase Experience } \\
\hline Insurance Benefits & & & & & & & & \\
\hline
\end{tabular}

For the five main criteria, the weight value of insurance benefits (0.34945) was higher compared to that for other items, and had the highest weight for expert opinions overall and in each field. The lower insurance benefits were salesperson quality (0.20368), corporate image (0.17543), purchase experience (0.17357), and access to purchase (0.09786). These results indicate that consumers primarily consider insurance benefits when making overseas travel insurance purchasing decisions, including insurance content and the coverage value. This key factor significantly affects consumers purchasing overseas travel insurance, and helps salespeople and insurance companies understand how to help customers plan their 
overseas travel insurance. Furthermore, it clarifies what consumers consider as important.

The next most heavily weighted main criterion, salesperson quality $(0.20368)$, receives the most attention from academia and governments. This indicates that consumers hope that the salespeople with whom they interact are able to meet customer requirements, provide optimal service, understand customer demands, and design the desired policy based on academic background, years of experience, professional certification, professional knowledge, or service attitude. In reality, this creates win-win situations for both customers and salespersons.

According to industry experts, purchase experience (0.24253) was the second most heavily weighted consideration, indicating that consumers will use their previous purchase experiences as a reference for further purchases. This also indicates to salespersons that consumers' future purchases will be affected by salespersons' service attitude. Tables XIII and XIV provide the summaries of the main criteria, sub-criteria, weights, and rankings.

Tables XIII. Weights of overall criteria

\begin{tabular}{|c|c|c|c|c|c|}
\hline Main criteria & Weight & Rank & Sub-criteria & Relative weight & Rank \\
\hline \multirow{5}{*}{$\begin{array}{l}\text { Corporate } \\
\text { Image }\end{array}$} & \multirow{5}{*}{0.17543} & \multirow{5}{*}{3} & A1. Reputation & 0.11874 & 4 \\
\hline & & & A2. Claims Service & 0.41728 & 1 \\
\hline & & & A3. Service Location & 0.15259 & 3 \\
\hline & & & A4. Financial Health & 0.21509 & 2 \\
\hline & & & A5. Member of Holding Company & 0.09626 & 5 \\
\hline \multirow{5}{*}{$\begin{array}{l}\text { Salesperson } \\
\text { Quality }\end{array}$} & \multirow{5}{*}{0.20368} & \multirow{5}{*}{2} & B1. Professional Knowledge & 0.29924 & 2 \\
\hline & & & B2. Service Attitude & 0.37189 & 1 \\
\hline & & & B3. Academic Background & 0.06519 & 5 \\
\hline & & & B4. Years of Experience & 0.10715 & 4 \\
\hline & & & B5. Professional Certification & 0.01565 & 3 \\
\hline \multirow{6}{*}{$\begin{array}{l}\text { Access to } \\
\text { Purchase }\end{array}$} & \multirow{6}{*}{0.09786} & \multirow{6}{*}{5} & C1. Life Insurance Company & 0.19578 & 1 \\
\hline & & & C2. Property Insurance Company & 0.19071 & 2 \\
\hline & & & C3. Insurance Broker & 0.14046 & 5 \\
\hline & & & C4 Online Purchase & 0.12874 & 6 \\
\hline & & & C5. Call-In Card & 0.18359 & 3 \\
\hline & & & C6. Airport Counter & 0.16071 & 4 \\
\hline \multirow{3}{*}{$\begin{array}{l}\text { Purchase } \\
\text { Experience }\end{array}$} & \multirow{3}{*}{0.17357} & \multirow{3}{*}{4} & D1. Relative, Friend, and Family & 0.34953 & 2 \\
\hline & & & D2. Previously Used Insurance Company & 0.24715 & 3 \\
\hline & & & D3. Salesperson of Previous Policy & 0.40332 & 1 \\
\hline \multirow{5}{*}{$\begin{array}{l}\text { Insurance } \\
\text { Benefits }\end{array}$} & \multirow{5}{*}{0.34945} & \multirow{5}{*}{1} & E1. AD \& D & 0.26137 & 1 \\
\hline & & & E2. Accidental Outpatient and Hospitalisation & 0.21081 & 3 \\
\hline & & & $\begin{array}{l}\text { E3. Sudden Illness Outpatient and } \\
\text { Hospitalisation }\end{array}$ & 0.24784 & 2 \\
\hline & & & E4. Overseas Emergency Assistance & 0.18200 & 4 \\
\hline & & & E5. Loss of Property & 0.09800 & 5 \\
\hline
\end{tabular}




\section{Ml Macrothink}

International Journal of Human Resource Studies

ISSN 2162-3058 2019, Vol. 9, No. 1

Tables XIV. Weights and rankings of sub-criteria items

\begin{tabular}{lll}
\hline Sub-criteria & Relative weight & Rank \\
\hline A2. Claims Service & 0.41728 & 1 \\
D3. Salesperson of Previous Policy & 0.40332 & 2 \\
B2. Service Attitude & 0.37189 & 3 \\
D1. Relative, friend, or family & 0.34953 & 4 \\
B1 Professional Knowledge & 0.29924 & 5 \\
E1. AD \& D & 0.26137 & 6 \\
E3. Sudden Illness Outpatient and Hospitalisation & 0.24784 & 7 \\
D2. Previously Used Insurance Company & 0.24715 & 8 \\
A4. Financial Health & 0.21509 & 9 \\
E2. Accidental Outpatient and Hospitalisation & 0.21081 & 10 \\
C1. Life Insurance Company & 0.19578 & 11 \\
C2. Property Insurance Company & 0.19071 & 12 \\
C5. Call-In Card & 0.18359 & 13 \\
E4. Overseas Emergency Assistance & 0.18200 & 14 \\
C6. Airport Counter & 0.16071 & 15 \\
A3. Service Location & 0.15259 & 16 \\
C3. Insurance Broker & 0.14046 & 17 \\
C4 Online Purchase & 0.12874 & 18 \\
A1. Reputation & 0.11874 & 19 \\
B4. Years of Experience & 0.10715 & 20 \\
E5. Loss of Property & 0.09800 & 21 \\
A5. Member of Holding Company & 0.09626 & 22 \\
B3. Academic Background & 0.06519 & 23 \\
B5. Professional Certification & 0.01565 & 24 \\
\hline & & \\
& &
\end{tabular}

\section{Conclusions and Recommendations}

\subsection{Conclusions}

The results of the analysis in this study show that among the main criteria for travel insurance, "insurance benefits" was weighted most heavily. This indicates that consumers care most about their insurance benefits when considering factors in purchasing travel insurance products. When travelling overseas, the location of travel is often far from one's home and has a different lifestyle. As such, it is difficult to estimate the potential cost when accidents occur; thus, consumers hope to purchase travel insurance before going abroad to provide themselves with maximum benefits and minimise their losses. This is consumers' primary consideration in terms of the evaluation criteria. The second most important criterion was "salesperson quality," indicating that consumers are extremely attentive to those with whom they interact when purchasing products. Typically, consumers obtain most of their travel insurance information from salespersons, meaning that they typically trust the descriptions 
they provide during the sales process. Consumers hope that when claiming insurance benefits, their claims meet the conditions claimed by salespersons during the purchase. As such, consumers consider the quality of salespersons as important.

Among the sub-criteria for travel insurance, "claims service" has the highest weighted value. When travelling, travellers typically maintain a carefree attitude, and when they suffer injury, hospitalisation, or death because of a sudden accident during their travels, they and their family members are often unsure of how to handle the situation. In addition, medical treatment costs are expensive, and thus, travellers often struggle with transportation when moving to and from their homes. These problems may exhaust travellers, but if they can obtain a claim service from their insurers, such as claim disbursements, overseas emergency assistance, and medivac services, their concerns related to money can be eliminated, which may help them calmly choose higher-quality medical treatment. Financial assistance helps ease the frustration of such moments, which is why good claims service is considered the most important determining factor when travellers purchase insurance. In summary, when consumers engage in travel activities, the key factors they consider in terms of travel insurance are the maximisation of personal benefits from the policies sold by an insurance company - "insurance benefits"- and the insurance payouts and extended service offered by the company in the event of an accident, namely "claims service."

Regarding the main criteria, "salesperson quality" had the second highest weighted value, showing that in addition to personal benefits, consumers emphasise the salespersons with whom they interact. Often, consumers base their purchasing decision on the information provided by salespersons, and hope that the promises made represent the stance of the company. As such, their understanding of the real nature of their policy depends strongly on the salesperson. Furthermore, for the sub-criteria, "salesperson of previous policy" was the second most heavily weighted factor, followed by "service attitude." Both these indicate the importance of salespersons.

According to the results of this study, the top ten criteria in terms of weight are "claims service"; "salesperson of previous policy"; "service attitude"; "relatives, friends, and family"; "professional knowledge"; "AD\&D"; "sudden injury outpatient and hospitalisation"; "previously used insurance company"; "financial health"; and "accidental outpatient and hospitalisation." Based on the observations above, when consumers make purchase evaluations, their 10 primary considerations are the scope of post-purchase claims service, trust in the salesperson of their previous policy, attitude of the salesperson during sales, introductions by relatives and friends, and purchasing access, demonstrations of professional knowledge by the salesperson, and assistance in the event of AD\&D. The handling of medical treatment resulting from a sudden illness while overseas, trust in a previously used insurance company, financial health of the company from which they purchase a policy, and making claims after accidents are important factors while travelling. During the sales process, rapid and successful sales depend on key explanations to achieve mutually beneficial outcomes for the consumer, company, and salesperson. 


\subsection{Recommendations}

Based on the findings of this study, the authors propose the following recommendations:

(1) Life and property insurance companies sell travel insurance products. There are significant differences and similarities between these two types of insurance companies. However, because consumers depend on salespeople for travel insurance, they do not compare the insurance content offered by life and property insurance companies. This study suggests that people purchase policies from holding companies, because they own both life and property insurance companies, meaning that they share the same sales channels and can introduce differences in policies and conduct comparative analyses.

(2) During the pre-departure meetings held by travel agencies, insurance salespeople should also introduce the content of travel insurance so that travellers understand the protection and benefits offered. Thus, if travellers are sceptical about the content of a policy, want more detailed information, or want to understand a shortcoming of a policy, professional insurance salespeople can immediately respond and make additions. This allows travellers to shift their risk to the insurance policy, and such service will improve consumers' perception of the travel agency.

(3) We recommend that to improve their visibility, property insurance companies target "young people" and advertise travel insurance products on a website. These companies can also join forces with other travel agencies to place product advertisements on travel agency platforms. This will allow consumers to increase their information on travel insurance products and enable travellers to reduce their financial losses during travel.

(4) In recent years, an increasing number of sudden illnesses such as stroke and myocardial infarction occur during travel. When these occur overseas, the cost can be impossible to estimate. If a medical evacuation is required, these costs will increase. As such, when consumers buy travel insurance products, we suggest that they not only consider accidental coverage, but also sudden illness plans. Currently, insurance companies have multiple plans covering sudden illnesses aimed at travel to Europe and the Americas.

(5) Call-in cards are convenient for today's busy consumers, and we recommend that salespeople not only sell insurance plans, but also actively promote and explain call-in cards when engaging with consumers to encourage them to sign up sooner. This makes it easier for consumers to purchase policies rapidly in the future, saving their time and that of salespersons. In addition, consumers can obtain direct discounts when purchasing a policy over the telephone, satisfying their desire for convenience.

(6) Consumers also emphasise the financial health of insurance companies. If insurers can become part of a holding company, they can offer a broader range of products, and salespeople can become more neutral in their sales. This study recommends that when travellers participate in a travel agency's itinerary, they should purchase travel insurance from a life insurance company, because the travel agency has already taken out liability insurance from a property insurance company, meaning that one needs only to add a personal insurance policy. When travelling independently, this study suggests prioritising travel insurance from a 
property insurance company. This will greatly improve consumer approval of the insurance company and salespersons.

\section{References}

Bai, X. (2010). Research on the factors that consumers consider when purchasing consumer injury insurance products, unpublished master thesis, National Kaohsiung University of Applied Sciences, available at: URL if freely available on the internet (accessed date).

Chang, S. (2013). Research on the influencing factors of tourist travel insurance consumption behaviour, unpublished master thesis, Nanhua University, available at: URL if freely available on the internet (accessed date).

Chang, Y. (2002). Research on the purchase behaviour of investment-type life insurance commodities - empirical analysis from consumer risk values, unpublished master thesis, Feng Chia University, available at: URL if freely available on the internet (accessed date).

Deng, Z., \& Ceng, G. (1989). Connotation and application of hierarchical analysis (AHP), Chinese Journal of Statistics, 27(6), 5-20.

Engel, J. F., Blackwell, R. D., \& Miniard, P. W. (1993). Consumer behavior (7: e uppl.).

Fang, H., \& Li, H. (2004). Consumers' preference for purchasing life Insurance marketing channels-taking Taichung citizens as an example, Life Insurance Quarterly, 134(1), 29-55.

Gee, C. Y., Makens, J. C., \& Choy, J. L. D. (1996). The Travel Industry (3rd ed.), New York: Van Nostrad Reinhold, 50.

Huang, J. (2007). Brand quality, service, promotion activities, research on the impact of purchasing decisions, unpublished master thesis, Yishou University, available at: URL if freely available on the internet (accessed date).

Jian, B. (2008). The key factor in the evaluation criteria for consumers to purchase investment-type insurance products - hierarchical analysis application, unpublished master thesis, Tunghai University, available at: URL if freely available on the internet (accessed date).

Kotler, P. (1997), Marketing Management: Analysis, Planning, Implementation and Control, Englewood Cliffs, Prentice Hall, Inc., NJ.

Lin, S., \& Ding, X. (1999). Discussion on the influencing factors of capital structure and empirical research, Enterprise Bank Quarterly, 23(2), 139-154

Morrison, M. A. (1997), Hospitality and Travel Marketing, Delmar Publishers, Albany, New York.

Qiu, Y. (2006). Consumers' knowledge and purchase intention of travel insurance for property and casualty insurance, unpublished master's thesis, Fengjia University, available at: URL if freely available on the internet (accessed date).

Saaty, T. L. (1980), The Analytic Hierarchy Process, McGraw-Hill, New York. 


\section{Macrothink}

International Journal of Human Resource Studies

ISSN 2162-3058 2019, Vol. 9, No. 1

Saaty, T. L. (1990). How to make a decision: the analytic hierarchy process, European Journal of Operational Research, 48(1), 9-26. https://doi.org/10.1016/0377-2217(90)90057-I

Schiffman, L. G., \& Kanuk, L. L. (1987). A market's segments. Marketing News, May, 59-64.

Schiffman, L. G., \& Kanuk, L. L. (2003), Consumer Behavior. Upper Saddle River, Pearson Education, Inc., NJ.

Slovic, P. (1987). Perception of risk, Science, No. 236, pp. 280-285. https://doi.org/10.1126/science.3563507

Song, W. (2005). Consumers' knowledge of insurance for property and casualty insurance, unpublished master thesis, Fengjia University, available at: URL if freely available on the internet (accessed date).

Tsai, K. (2005). An empirical study of domestic best-selling book purchasers, unpublished master thesis, Nanhua University, available at: URL if freely available on the internet (accessed date).

Wilks, J. (2004). Injuries and injury prevention, in J. Keystone, P. Kozarsky, D. Freedman, H. Nothdurft and B. Connor (Ed.), Travel Medicine, pp. 453-459.

$\mathrm{Wu}$, M. (2003). Research on tourism risk cognition and travel insurance purchasing behaviour of Chinese travel abroad, unpublished masters thesis, Cultural University, available at: URL if freely available on the internet (accessed date).

Yan, H. (2005). The influence of personality traits, life style and tourism risk perception on tourism insurance consumption of the national primary school teachers-Taking Kaohsiung County as an example, unpublished master thesis, National Kaohsiung First University of Science and Technology, available at: URL if freely available on the internet (accessed date).

Yang, X. (2011). Research on ecotourism hazard and insurance planning, unpublished master thesis, Tamkang University, available at: URL if freely available on the internet (accessed date).

Yu, C., \& Zhang, J. (1997). Analysis of Taiwanese companies adopting good cause marketing, Asia Pacific Management Review, 2(2), 59-82.

\section{Copyright Disclaimer}

Copyright for this article is retained by the author(s), with first publication rights granted to the journal.

This is an open-access article distributed under the terms and conditions of the Creative Commons Attribution license (http://creativecommons.org/licenses/by/4.0/). 